\title{
THE USE OF SPECIAL ASSESSMENT DISTRICTS AND INDEPENDENT SPECIAL DISTRICTS AS AIDS IN FINANCING PRIVATE LAND DEVELOPMENT
}

In order to meet California's ever increasing demand for developed land suitable for residential and commercial building, land developers have long sought ways to finance the acquisition and development of undeveloped raw acreage which then could be subdivided into individual parcels and sold, either as lots suitable for building, or as lots with houses already constructed. Each county in California is required by the Subdivision Map Act ${ }^{1}$ to enact ordinances governing the design and improvement of subdivisions. This Act has two basic objectives: first, to coordinate the subdivision plans and planning, mcluding lot design, street patterns, rights of way for drainage and sewers, with the community plan as established by the local planming authorities; second, to insure that the areas dedicated for public purposes by the filing of subdivision maps, including public streets and other public areas, will be properly improved initially by the subdivider so that they will not become an undue burden in the future upon the general taxpayers of the community. ${ }^{2}$ These improvements are costly. ${ }^{3}$ Developers can provide them, lowever, at no cost to themselves by using one of the numerous statutory procedures under which special assessment districts or special districts may be formed.

Legislative scrutiny of the use of special assessment districts and special districts in land development operations has been intensive simce 1962, when investigation by the district attorney of Santa Barbara County into charges of trust deed manipulation in connection with the Embarcadero Municipal Improvements District disclosed irregnlarities in the affairs of

${ }^{1}$ CaI. BUS. \& Prof. Code $\S \S 11500-11658$. This Act is "primarily an overall statewide enabling act [requiring] . . . the enactment of subdivision ordinances by local governmental bodies having direct jurisdiction over subdivisions in the commurities affected. . . . Direct control of the kind and type of subdivisions to be platted in each community and the physical improvements to be installed are left to the control of the local jurisdictions within certain general himits specified in the statewide Subdivision Map Act." SENate INTERIM Comomitree on Subdivision Developanent and Planning, Subdivision Manual 21 (1959).

2 Ibid.

3 Milton G. Gordon, California Real Estate Commissioner, in testimony before the Assembly Interim Committee on Municipal and County Government, outlined the three stages of subdivision development as, (1) land acquisition, (2) development of off-site improvements (streets, sewers, storn drains, utilities, etc.), and (3) the construction of residences. Trust deed financing is often available for acquisition, and construction is financed by support of VA or FHA guaranteed loans or other conventional loans. Off-site improvements, he testified, are the most difficult for the subdivider to finance. Transcript of Proceedings [hereinafter cited as Proceedings] before the Assembly Interim Committee on Municipal and County Government [hereinafter cited as the Committee] on the Subject of Tax Exempt Bonds to Assist Land Development [hereinafter cited as Tax Exempt Bonds] 34 (Jan. 17, 1964). 
that public corporate entity. The Assembly Interim Committee on Municipal and County Government has since held a series of hearings on various aspects of the land developer's use of improvement areas and special districts. ${ }^{4}$ Recommendations based on the Committee's findings were submitted to the 1963 legislature $^{5}$ and were enacted into law substantially as recommended. The Committee has promised a vigorous program in the 1965 legislative session. ${ }^{\circ}$

The purpose of this Comment is to discuss the use of these districts by private developers and the recent corrective measures taken to avoid abuse.

I

THE PROCEDURES: WHY THEY ARE USED

The chief reason that improvement areas and special districts are attractive to land developers is that through their use bonds may be sold to the public to finance public improvements. The developer is thereby relieved of the need to supply his own money or credit to finance this stage of the subdivision operation. These bonds are considered public bonds, bearing the name of the State of California and the name of the city or county where the improvement area or special district is located.? Bonds under either category are considered obligations of a political subdivision of a state, and interest earned on such obligations is, for purposes of the federal income tax, tax exempt. ${ }^{8}$ This feature, which is very attrac-

4 Proceedings of the Committee on the Subject of the Improvement Acts of 1911-13-15 [hereinafter cited as Improvement Acts] (June 18, 19, 1962); Proceedings before the Committee on the Subject of Independent Special Districts Used in Land Development Situations [hereinafter cited as Independent Special Districts] (Sept. 24, 25, 1962); Proceedings re Tax Exempt Bonds (Jan. 17, 1964); Proceedings before the Committee on the Subject of Control of Special District Indebtedness [hereinafter cited as Special District Indebtedness] (Sept. 15, 1964).

56 Comaltree, final Report No. 20 on the Uses of Spectal Assessurent Procedures and Independent Special Districts to Am Land Developament [hereinafter cited as Final REPORT] 26-27 (1962).

6 San Francisco Chronicle, Dec. 3, 1964, p. 61, col. 1.

7 For example, Bonds of the Estero Municipal Improvement District are entitled: "United States of America, State of California, County of San Mateo," and then in sniall print, "Estero Municipal Improvement District." Proceedings re Independent Special Districts at 144.

8 INT. REv. CoDE of $1954 \S 103$ (a). "Gross income does not include interest on (1) the obligations of a State, a Territory, or a possession of the United States, or any political subdivision of any of the foregoing ...."

Much of the problen would be moot should Congress renove the exenption on interest from state and local obligations altogether. Opinions vary as to whether there are constitutional limitations to such action. The prevailing opinion is that there are not. See, e.g., 1 CCH 1965 Stand. Fed. TAX Rep. II 947.016.

Special assessnent districts are included in the definition of political subdivision, even 
tive to high tax-bracket investors, ${ }^{9}$ ordinarily permits marketing these bonds at a lower interest rate than non tax-exempts of equal quality. ${ }^{10}$

The principal contention made by proponents of this method of financing is that the normal private money market either cannot provide the necessary financing or can do so only at a prohibitive cost. ${ }^{11}$ The developer can use bond investors' money and shift the cost directly to the ultimate lot purchasers. He can then, in effect, sell the developed lots at a lower price than would be possible under conventional financing, since he has only to recoup the acquisition and construction costs and can leave the costs of the public improvements to be met through tax payments. Any savings realized in the public improvement stage by the use of cheaper money acquired through sale of tax exempt bonds should ultimately find

if the obligations are to be satisfied out of special funds and not out of general funds or taxes. Treas. Reg. \& 1.103-1 (1956).

The same regulation provides that "political subdivision" denotes any division of a state to which has been delegated the riglit to exercise part of the sovereign power of the state and may or may not include districts such as reclamation, irrigation and similar divisions and districts. Water districts, Rev. Rul. 58-452, 1958-2 CuM. Bunr. 37, and soil conservation districts, Rev. Rul. 59-373, 1959-2 CuM. BuxI. 37, have been ruled pohtical subdivisions on the authority of the leading case, Commissioner v. Slamberg's Estate, 144 F.2d 998 (2d Cir. 1944), cert. denied, 323 U.S. 792 (1945), since they were divisions of the state formed to achieve a recognized public purpose whose assets and revenue inured to the benefit of the state, even though the sovereign powers delegated were limited in degree and the obligations issued pledged only the credit of the subdivision and not that of the state. Rev. Rul. 59-373, 1959-2 Com. Burr. 37, 38.

${ }^{\circ}$ Sec, e.g., Rogers, 1911 Act Bonds, 36 S. BAR J. 323-24 (1961).

10 See, e.g., United States Advisory Commisston on Intergovernmental Relations, INdostriat Deveiopment Bond Financing 3 (June 1963).

11 See, e.g., testimony of T. Jack Foster, developer of Foster City (the Estero Mumicipal Improvement District) in Proceedings re Independent Special Districts at 90 . "In order . . . to purchase the land, to bring in a water line big enough to supply a city of 35,000 residents and to do the necessary reclamation work, etc., [it] was going to take an estimated $\$ 25,000,000$ to $\$ 30,000,000$. It would be absolutely impossible to borrow this money on a long term basis because banks don't loan money of that kind on a long term basis. You can only borrow money, as you gentlemen know, for eighteen months to two years at a time."

See also testimony of Sierra Lakes County Water District developer, Frank Allen. "We tried to get outside financing, and it appeared to be rather ridiculous." Proceedings re Special District Indebtedness at 63. For a discussion of how legal and economic changes in the functioning of institutional lenders has curtailed the availability of long term capital, see Pinsky, State Constitutional Limitations on Public Industrial Financing: An Historic and Economic Approach, 111 U. PA. L. REv. 265, 273-74 (1963), and sources cited thercin. While the argument has validity with respect to projects on the Foster City scale, it is less convincing as the size of the contemplated project diminishes. Whereas one effect might be to give sound developers a needed alternative financing method, another might be that projects which a developer of normal financial responsibility could undertake on his own credit are undertaken instead by one whom the private money market mistrusts. It seems reasonable to assume that the feasibility of the proposed project influences the rates of the money lender. Relegating higl risk enterprise to public finance while private enterprise stays with low risk ventures may well appear anomalous to many observers. 
its way to the lot purchaser since he must either pay bond principal and interest, or, if his lot was improved through conventional financing pay that amount required to reimburse the developer for privately financing the improvements. ${ }^{12}$ Yet this benefit to the purchaser may for a variety of reasons fail to accrue. ${ }^{13}$

\section{II}

\section{THE PROCEDURES: HOW THEY ARE USED}

There are two general categories of public developmental aids with which this Comment is concerned, ${ }^{14}$ and it may be well to carefully distinguish them at the outset, since both are customarily referred to as districts. The special assessment district is a geographical area within an already existing entity. It is utilized by the entity to define the area, benefited by specific public improvements, which shall bear the cost of the improvements. Each lot $m$ the area is assessed im proportion to the benefit which the lot derives from the improvement. Special assessinent districts will hereinafter be referred to as improvement areas.

The second category, the special district, is an independent corporate entity, governed by its own board of directors. ${ }^{16}$ The district exercises

12 See testimony of bond counsel Kenneth I. Jones in Proceedings re Special District Indebtedness at 37-38. The lot purchaser would ordinarily have to pay mortgage interest on that part of the purchase price which represents public improvements as well as on that part which represents acquisition and construction costs. This may be made clearer by example. Assume a cost of $\$ 5000$ per developed lot for public improvements, and a cost of $\$ 25,000$ for acquisition and construction. Assume the cost of borrowing to be eight percent, and the alternative, bond interest, six percent. The developer who borrows the money must collect $\$ 5400$ from the purchaser to reimburse himself for the cost of the public improvements. This becomes part of the purchase price and ordinarily must he borrowed and paid off at mortgage interest rates. The alternative, bond sale, would mean that the purchaser would have to "pay back," through yearly tax payments, not $\$ 5400$ at mortgage interest rates, but $\$ 5000$ at bond interest rates.

13 See, e.g., the statement of Paul J. Anderson, Second Vice President of the County Supervisors Association of California and Chairman of their Urban Problems Committee, "The sale of the property does not reflect the lower outlay of private investment but the developer receives the 'gomg price' and the purchaser has to pay the additional costs through higher taxes for many years." Proceedings re Tax Exempt Bords at 4.

14 Programs such as Urban Renewal and FHA and VA loans and insurance could also be termed public developmental aids.

16 There are two historical lines of development under which the use of special districts in land devclopment has evolved. As early as 1868 the Legislature hegan authorizing districts to aid the state in reclaiming, improving, and increasing the productivity of farm and agricultural lands. Although such districts provide a specific local improvement, they have received judicial approval because at the same time they are a source of broad public benefit to the state at large; the state therefore could have undertaken the local improvement itself and financed it out of state funds; the decision to finance by the alternate special district method is within the state's discretion. A different and distinct category of special districts comes under art. XI, § 19 of the California constitution, adopted in 1911, which authorized "any municipal corporation to establish and operate public works for supplying 
such powers and functions of government as may be conferred by the statute under which it is created. ${ }^{16}$ Often included are the powers to borrow money, issue bonds, create special improvement areas, and levy taxes. $^{17}$

\section{A. The Improvement Area Acts}

A large proportion of the public improvements constructed by Cahifornia municipalities is financed through the assessment procedures of either the Improvement Act of 1911 or the Municipal Improvement Act of 1913, used in conjunction with the bond provisions of either the Improvement Act of 1911 or the Improvement Bond Act of $1915 .^{18}$ These procedures are also available for use by land developers opening new subdivisions. ${ }^{10}$

A subdivider may ask the local legislative body (city council, county board of supervisors, or special district governing board) to constitute his property an improvement area in order to finance the public improvements required by the local ordinances implementing the Subdivision Map Act ${ }^{20}$

its inhabitants with light, water, power, heat, transportation, telephone service or other means of communication." Statutes based on this provision have authorized the creation of numerous disricts, including county water districts, public utility districts and community service districts, all of which generally are termed quasi-municipal corporations. Their purpose is to provide the residents of an unincorporated community with the facilities and advantages of urban life without creating a full mumicipal corporation. 6 Comosirtee, FINAT REPORT 26-27.

16 Latest reports show that Califormia has 3,342 special districts (excluding school districts and irrigation districts which are separately reported) falling into forty-nine categories, whose formation and operation are authorized and controlled by 174 different statutes. - Fifty-six of these statutes are general enabling provisions under which districts may be created. The remainder are single special acts authorizing particular special districts. Calmfornia State Controller, Annuat Report of Financial Transactions Concerning Speciat. Districts of Calmornta iii, 19-22 (Fiscal Year 1962-63) [hereinafter cited as CONTROLIER's ANNUAL REPORT].

17 Public improvenients that benefit the entire district will be financed by issuing general obligation or revenue bonds which will have the taxing power of the district, or the revenue earned by the facility, as security. Improvements benefiting a specific arca within the district will be financed by assessment procedures and assessment bonds.

18 Rogers, supra note 9, at 323. Bonds issued under the 1911 Act are issued in the aniount of the unpaid assessments and are secured solely by the property assessed. Each parcel of property stands as security to the bondliolder for the obligation owed by the owner of that parcel. Bonds issued under the 1915 Act are issued in even denominations and are secured primarily by a fund in which the individual assessments, when collected, are placed. The entity which collects the assessments and authorizes the bonds is contingently liable on the bonds and must replace any deficit in the special fund by means of a specified general ad valorem tax. The 1915 Act is seldon employed in single owner-developer situations, since local legislative bodies are understandably less than anxious to pledge the taxing power of the entire entity as contingent security for one subdivision development.

10 The Committee focused its attention on this aspect in hearings held in Sacraniento in June of 1962. Proceedings re Improvement Acts.

20 The Subdivision Map Act requires that local jurisdictions enact ordinances relating to "improvement" and "design" of subdivisions. Business and Professions Code $\$ 11511$ provides that the word "improvement" refers only to such strect work and utilities to be 
and any other improvements authorized by the particular Improvement Act which would tend to make the developed property more salable. ${ }^{21} \mathrm{He}$ may contract with the legislative body, as a condition for acceptance of his subdivision map, to initiate and consummate special assessment proceedings. ${ }^{22}$ The legislative body then passes a resolution announcing its intention to create a public improvement.

In the case of the 1911 Act, ${ }^{23}$ notice is then given to any property owners whose property is in the proposed area, and a hearing is held. If, after the hearing, the legislative body decides to proceed with the work, public bids are solicited and a contract is let for construction. The owners of three-fourths of the lands liable to be assessed, that is, the developers, may elect to take the contract at lowest bid price and do the work themselves. After construction of the project, the cost is tentatively apportioned among the property owners. Another hearing is lield at which the property owner may protest the assessment. At the conclusion of this hearing, the legislative body affirms the assessment, and a lien attaches to each piece of property involved in the amount of the individual assessment. The contractor is presented with three documents-the assessment roll, assessment dia-

installed on the land to be used for public and private streets, highways, ways, and easements, "as are necessary for the general use of the lot owners in the subdivision[,] and local neighborhood traffic and drainage needs. . . Section 11510 states that the word design refers to grades, alignment and widths of streets and of easements and rights of way for drainage and sanitary sewers, and to minimum lot area and width. Kelber v. City of Upland, 155 Cal. App. 2d 631, 318 P.2d 561 (1957). The kind and type of public improvements required are specified by local ordinance. See note I supra.

21 The authorized improvements are generally co-extensive with those required by local subdivision ordinance, i.e., grading, sidewalks, sewers, drains, lighting facilities, fire and flood protection facilities, water supply, gas supply. Improvements authorized but less likely to be required by a subdivision ordinance include bomb or fallout shelters, ornamental vegetation, and navigation facilities. CAL. STS. \& Higrs. CODE § 5101 (1911 Act); CAI. STs. \& Hrgrs. CODE $\S 10100$ (1913 Act). Both statutes contain an omnibus elause authorizing "All other work which may be deemed necessary to improve the whole or any portion of such streets, places, public ways or property, or rights of way owned by such . . . [entity]." (1911 Act) and "Any works, utility, or appliances necessary or convemient for providing any other public service." (1913 Act).

22 CaI. Bus. \& Pror. Code \& 11611. The practice of allowing subdividers to form improvement areas apparently had its statutory birth in California in 1929. The Subdivision Map Act, Cal. Stats. 1929, ch. 837, provided that "subdivision regnlations may provide that any subdivider at his option in beu of the contract to construct improvements and the bonds herein provided for may enter into a contract with the city or county secured by a faithful perfornance bond in a sum not to exceed the estimated cost of said improvements for which he agrees within such time as may be provided in said contract to initiate, and, so far as may be in his power, to consummate proceedings under an appropriate special assessment act for the formation of a special assessment district covering such subdivision or part thereof for the financing and construction of the designated improvements upon the streets, highways and rights of way dedicated by such map." Cal. Stats. 1929, ch. 837 \& 30 (d), at 1801-02.

23 CAL. SxS. \& HigHs. COdE $\$ \S 5000-6794$. 
gram and a warrant-which together give him the authority to collect from each property owner the amount of the latter's individual assessment. To obtain payment the contractor can either collect unpaid assessments in cash or sell the right to collect. After thirty days the treasurer of the issumg entity must then issue bonds to the contractor or his assignee which represent the unpaid assessments. Commonly, the contractor assigns his interest in the documents to a bond underwriter who pays for the construction and then markets the bonds. ${ }^{24}$ Operation of the 1911 Act and similar acts may be streamlined in single owner situations, since the hearing and notice provisions are waivable. ${ }^{25}$

The Municipal Improvement Act of $1913,{ }^{26}$ is chiefly distinguishable from the 1911 Act in two ways. Perhaps the most important difference is that assessments are levied, bonds sold, and money made available to the public treasurer before the improvements are constructed. The contractor can receive progress payments during construction and is thereby relieved of the necessity of securing interim private financing. An assessment and an assessment diagram are prepared, based initially on an engineer's estimate of the total cost of the completed improvement. After a hearing, if the legislative body determines to proceed, it confirms the assessment, and a hen is created against the property. At the conclusion of a thirty-day period, in which owners may pay their assessments, bonds are sold to represent unpaid assessinents. ${ }^{27}$

The second distinguishing feature relates to the term "acquisition." The 1911 Act is primarily designed to finance the construction of improvements, with only limited provision for acquiring improvements already existing. The 1913 Act, on the contrary, permits the acquisition of preexisting improvements.

By an unusual construction of the Act, these acquisition provisions were utilized in some cases to avoid salutary public safegnards in the construction of new improvements. The construction provisions call for public bids and performance, labor and materialmen's bonds. These provisions do not apply in acquisition situations since the improvement has already

241911 Act improvements and 1913 Act improvements may be financed by either 1911 Act bonds or 1915 Act bonds. See note 18 supra.

25 CAL. StS. \& Highs. CoDE $\S 5132$. The Committee found no abuses of the 1911 Act and sanctioned its continued use in single owner-developer projects. 6 CoManITtEE, Finar Report 17. A series of technical changes designed to correct ambiguities, eliminate deadwood and consolidate duphicating provisions were enacted pursuant to the Committee's recommendations. Id. at 37-40.

26 Cat. StS. \& Hrges. CODE $\$ \$ 10000-609$.

27 Again, as under the 1911 Act, the bonds may be 1911 Act bonds, in which case they represent and are secured by a specific piece of property, or they may be 1915 Act bonds, in which case they are secured by a fund and, contingently, by the taxing power of the issuing entity. 
been constructed. It was found, however, that developer improvement areas were "acquiring" improvements not already constructed by the simple expedient of "acquiring" in stages. After the formation of the assessment area and the estimate of cost and sale of bonds, the developer, having elected to take the improvement contract himself, would construct perhaps ten percent of the improvement. The engineer would certify its completion, and the local treasurer would make payment from the bond proceeds, thereby "acquiring" ten percent of the improvement, and so on. ${ }^{28}$ Since they were "acquiring" rather than "constructing," the bid and bond requirements did not apply.

One developer successfully persuaded a county board of supervisors to waive the usual subdivision bond authorized by the Subdivision Map Act on the strength of his agreement to finance off-site improvements by means of an assessment district. ${ }^{29}$ The cost was poorly estimated, and the developer misappropriated funds to his personal use. As a result there was not enough inoney to complete the improvements. Many of the bonds went into default and were foreclosed. There was no surety bond, since the improvements were "acquired" rather than constructed, so there was no one with the financial responsibility to complete the streets, water lines, sewer lines, and storm drains. ${ }^{30}$ Another instance attributable to the same loophole arose in a project which imvolved reclaiming marshland. In that situation there was no mishandling of funds, but merely an inaccurate engineering estimate. Yet once again there was no one with the financial responsibility to complete the improvements or pay the contractors when the bond money was exhausted. Good faith attempts were made by bond underwriters and bond counsel imvolved in these transactions to rescue the projects and assure their completion. As the Committee pointed out, however, this was a result of their integrity and good will and not the result of any legal safeguard. ${ }^{31}$

This dangerous aspect was remedied in the 1963 legislative session by specifying that the term "acquisition" as used in the 1913 Act referred only to items in existence on or before the date of adoption of the resolution of intent to acquire them, ${ }^{32}$ thereby bringing the bid and bond requirements to bear upon all construction.

286 ComantTeE, Finat RePORT 17.

29 CAI. BUs. \& Prof. CODE $\S 11612$ then authorized, but did not require, the local governing body to make the furnishing of sufficient bond to secure the agreement to improve the streets a condition of acceptance of the subdivision map.

30 Proceedings re Improvement Acts at 42-44, $205-08$.

316 Comartitee, Final Report 19.

32 CAL. Sts. \& HICHS. CODE $\S 10010$. The attorney general at the request of the then chairman of the committee had already issued a formal opinion that "to contend that construction can be accomplished within the meaning of the word 'acquire,' besides doing 
The second danger inherent in single owner-developer use of the 1913 Act was the potential for overburdening the land. ${ }^{33}$ Assessment liens, in some cases, were as high as eighty-five percent of fair market value. Consequently, the security for secondary encumbrancers, such as holders of trust deeds or purchase money inortgages, was very thin. As there was no provision for notice to encumbrancers of the commencement of assessment proceedings, even sophisticated lenders, such as a savings and loan institution, were unaware of the usurpation of the priority of their existing liens. ${ }^{34}$

The Special Assessment Investigation, Limitation and Majority Protest Act of $1931,{ }^{35}$ was designed to prevent such overburdening. The Act requires a finding by the local governing body, based on a detailed engineer's report, that a project is required by the public interest, convenience, and necessity and is financially feasible. The Act's provisions could be waived, however, by consent of four-fifths of the legislative body, or sixty percent of the affected landowners, and this waiver, in the case of single owner-developer situations, was standard operating procedure. The 1963 Legislature responded to the overburdening dangers by amending the Special Assessment Investigation, Limitation and Majority Protest Act to broaden the definition of owner, for purposes of waiver of the Act's provisions, to include any mortgagor or beneficiary under any existing mortgage or deed of trust. ${ }^{36}$ The amendments also require that any owner-subdivider, who contracts to institute assessment proceedings in conformity with the Subdivision Map Act, ${ }^{37}$ must convince the local legislative body that the assessment proceedings will not encumber the land beyond seventy-five percent of fair market value. ${ }^{38}$ To remedy the lack of notice to prior encumbrancers, a new division entitled "Notice of Special Assessment and Foreclosure Proceedings" was added to the code, ${ }^{30}$ which pro-

violence to the statutory definitions, also is diametrically opposed to the general scheme which the legislature has prescribed." 40 OPS. CAL. ATT'Y GEN. 125, 128 (1962).

33 This is perhaps the major problem with respect to developer use of improvement areas and special districts and is not confined to the 1913 Act.

34 Compurtee, Finai Report, 21 Cax. Sts. \& Highs. Code \$ 10428 provides that the special assessment lien under the 1913 Act "is paramount to all other liens, except prior assessments and taxation. ..." Special assessment liens are paramount to a mortgage existing at the time of the proceedings leading to the construction of the improvements. Cliase v. Trout, 146 Cal. 350,80 Pac. 81 (1905).

35 CAL. STS. \& HigHS. CODE $\$ \S 2800-3012$.

36 CAI. STS. \& HTGHS. CODE $\S 2804.2$.

37 CAL. BUS. \& Pror. CODE $\& 11611$, see note 22 supra and accompanying text.

88 CAI. STS. \& HIGES. CODE $\$ 2804.1$. Fair market value refers to the value of the land together with the constructed improvements. It must be kept in mind that as the ratio of debt to value increases, the availability of purchase inoney financing decreases. This in turn affects the salability of the developed property, which in turn affects price, and thus the value of the security.

39 CaI. Sts. \& HTGHS. CODE $\$$ 3100-24. 
vides for the filing of a map of the proposed district in the office of the county clerk at least fifteen days prior to the hearing on formation of the district, ${ }^{40}$ and for recordation of the notice of the confirmed assessment in the county recorder's office, rather than in the office of the superintendent of streets.

It had become the practice in some cases when using the 1913 Act to imclude as a part of the bond issue, under the otherwise proper heading of incidental expenses, a sum sufficient to service the bond-debt during the first year of its existence, when ordinarily the lots would not yet be sold. Such practice has been described as little more than "plainly a subvention to the developer who would otherwise have to make these payments with his own capital." 41 The Assembly Committee therefore recommended, first, that the concept of incidental expenses be clarified, and second, that the subvention be discontinued. The legislature clarified incidental expenses to exclude costs and expenses required in order to coinply with the Subdivision Map Act, such as map survey and engineermg costs, but it took no specific action on advance fundings of bond service costs. $^{42}$

\section{B. Special Districts}

The special district, as well as the improvement area, has proven attractive to land developers. The improvement area, as previously discussed, has no "powers" but is a place where certain improvements may be accomplished through use of the power to create assessment liens and issue bonds possessed by the corporate entity within whose bounds the area is located. The special district, on the other hand, once established, is an independent corporate entity with its own governing body whose powers are as broad as the statute under which it is created. ${ }^{43}$ The feature which distinguishes the special districts used by the land developer from any of the myriad other special districts in the state ${ }^{44}$ is that developerdistricts are employed not to meet the present need of residents of an unincorporated community for the facilities and advantages of urban life, but rather to provide the municipal services which future residents will want and need when, and if, the development has succeeded. The various acts presuppose the existence of a viable community which, througli the traditional checks and balances inposed by a broadly based suffrage,

40 CAL. STS. \& HTGHS. Code \$§ 3111-12.

416 Comamtree, Final Report 25. This practice probably does not of itself raise any question as to the validity of the bond issue, for it neither adds to nor subtracts from the one essential element which the proceedings require, that is, a "public purpose." See note 85 infra.

42 CAL. StS. \& HTGHS. CODE § 10204.1.

43 See note 15 supra.

44 See note 16 supra. 
would prevent the arbitrary use of district powers. Majority voter approval is ordinarily required for issuance of general obligation bonds. When the electorate is composed only of the developer and a few people whose liveliliood may depend upon the development project, little of the conventional safeguard remains. ${ }^{45}$

The Committee's liearings and investigations have disclosed that a number of types of special districts have proved attractive to land developers. The districts vary in name, in detail of formation, and in powers possessed, but they are essentially similar for purposes of this discussion. They provide a vehicle whereby a small number of persons may petition the local board of supervisors ${ }^{46}$ to hold an election for the purpose of forming a district and electing a board of directors. The petitioners, who generally may and often do comprise the whole of the electorate, can elect themselves or their nominees as directors. The district, acting through its directors, may then exercise its powers, which always include the power to borrow money and to issue bonds to finance whatever public improvements are desired and are allowed under its authorizing statute. The following are the districts upon which the Committee focused, ${ }^{47}$ and their reasons for domg so, together with remedial steps taken or proposed.

\section{Community Service Districts}

Community service districts ${ }^{48}$ are empowered to perform any combination of the following inunicipal functions: water supply, sewage disposal, garbage and refuse collection, fire protection, public recreation, street lighting, mosquito abatement, pohice protection, library services and street opening and construction. In so doing, they inay issue both general obligation and revenue bonds and may form special assessment districts (improvement areas).$^{49}$ A petition signed by the owners of twenty-five per-

456 Comamtitee, Finat Report 27.

46 Or hoards of supervisors, if the proposed district lies in more than one county.

47 Proceedings re Independent Special Districts; Proceedings re Tax Exempt Bonds; Proceedings re Special District Indebtedness.

48 CAI. Gov'T CODE $\S \S$ 61000-936. Cahforma has 122 community service districts. CoNTROLLER's ANNUAL REPORT at $x$. These districts are apparently the most attractive to land developers as may be understood by examining the scope of powers which the district can possess. One writer speaks of them as "jumior cities." Borrens, Spectal District Governacents IN THE UNTTEd States 109 (1957). The Committee's recommendations to the legislature in 1963 with respect to special districts were restricted primarily to commumity service districts and special act special districts (discussed infra in text accompanying notes 76-82). Consequently these districts require a more extended discussion than the other types of developer-districts.

49 General obligation bonds are secured by the taxing power of the entity, revenue bonds by the income from the operation of the facilities constructed with the hond proceeds. 
cent of the value of the land in the proposed district is sufficient to initiate formation proceedings.

The Committee found the act singularly suited to land development uses, but without "provisions which would prevent its use, and thus the use of public credit, in lighly speculative and marginal developments." $" 50$ One district, in the Mojave desert, was balancing revenues and expenses only by the expedient of continuing subsidization by the developer, until such time, as hopefully, demand for district services would approach supply. ${ }^{\text {.1 }}$ In Ventura County, a developer proposed to move some voters onto his ranch property in order to secure sufficient electors to form an autonomous district to allow him neans of financing both the normal subdivision improvements and, in addition, a golf course and clubhouse. ${ }^{52}$

The Commitee in 1962 recolnmended that three steps be taken with regard to developer use of community service districts: First, that a determination be made whether or not to contimue to allow the use of community service districts in land development; second, that a uniform system of accounting be adopted for all independent special districts; and third, that the local legislative body be required to find by exhaustive professional analysis that any proposed district be economically feasible before proceeding with formation of the district.

The 1963 legislature responded inferentially to the first recommendation, by taking no direct steps to curtail their use in land development. A uniform system of accounting was enacted as recommended whereby county auditors are to contract with public accountants for annual audits of special districts under the State Controller's administrative guidelines. ${ }^{\text {53 }}$ The third recommendation was met in two ways. The Community Service District Act was amended, giving the board of supervisors the discretion to termmate proceedings for formation if the board sliould find, "froin evidence taken at the hearing [that] the proposed district . . . is either not in the public interest or not economically feasible, or both." ${ }^{\text {. }}$ The second legislative response, part of a broadly based legislative program directed at the whole range of special district problems, including but by no means restricted to districts formed by developers, was the creation of local agency formation commissions.

A commission of five members exists in each county. Its function is to

506 Concorittee, Finai Report 30.

51 Proceedings re Independent Special Districts at 284.

52 Ventura County has since passed a resolution that it will not allow the use of a community service district for subdivision financing at all. Proceedings re Tax Exempt Bonds at 31.

53 Cax. Gov't Code § 26909.

54 Cax. Gov'T CODE § 61114. 
review proposals for incorporation of cities and creation of special districts. Factors to be considered in the review include, but are not limited to, demographic and topographic features; present and future needs for governmental services; present and projected costs and adequacy of services; possible alternative courses of action; the effect of the proposed formation and of alternative actions on adjacent areas, on mutual social and economic mterests and on the local governmental structure of the county. Commission disapproval termmates the proceedings; no new proceedings can be initiated for at least one year. Commission approval with modifications or conditions allows further proceedings only in compliance with such modifications or conditions. ${ }^{\text {s5 }}$

\section{County Water Districts}

A county water district $t^{56}$ may acquire, construct and operate facilities for supplying water, for collection, treatment and disposal of sewage, for providing fire protection, and for developing the recreational use of water. The district may borrow money, incur indebtedness, issue bonds, exercise eminent domain (not for solely-recreational purposes), form improvement districts, utilize the Improvement Act of 1911 and the Municipal Improvement Act of 1913, and exercise taxing power. The district may be formed by majority vote at an election held pursuant to a petition signed by ten percent of the registered voters in the proposed district. In two instances districts have been created with the signatures of only five and six electors: the district organizers and subsequent board of directors in the first case, and the developer, his wife, and four employees in the second. The districts were created to finance water supply and sewage disposal systems, and in one case, road construction. General obligation bonds and assessment bonds were issued. In one district, which has a $1,510,000$ dollar bond obhigation to meet as well as a 195,000 dollar purchase debt, taxes are twenty-mine dollars and fourteen cents per hundred instead of the three dollars and forty-three cents rate projected in the

65 CaI. Gov'T CODE §§ 54775-91. The Community Service District Act was amended in 1963 to provide, as an alternative to the autonomous board of directors, that the petitioners may ask the board of supervisors to whom the petition is addressed to serve as directors of the district. CAL. Gov' $x$ CODE $\S 61102.5$. One observer notes "Presumably, . . . the new local agency formation commissions could, if they saw fit, require district proponents to adopt the alternative." University of California, Berkeley, Institute of Governmental Studies, Scott \& Corzine, Special Districts in the San Francisco Bay Area: Some Problems and Issues, Oct. 1963, p. 43. The proposed Distriet Reorganization Act of 1965, Assembly bill 592, would, if enacted, give local agency formation commissions substantially the same power with respect to consolidation, reorganization, and dissolution of districts as they now possess with respect to formation of districts.

56 CAI. WATER CODE $\$ \S 30000-33901$. California has 200 county water districts. ConTROLIER'S ANNUAL REPORT at $x$. 
bond prospectus. ${ }^{57}$ Property owners in the district, other than the developer, received no personal notice of the creation of the district. ${ }^{58}$ The rising tax rate in the second district has discouraged many businesses which had been interested in locating in the district. ${ }^{59}$

Proposed new county water districts will henceforth be subject to local agency formation commission review. As an added safeguard the Coinmittee proposes to recommend to the 1965 legislature that all special districts used for promotional ventures in land development come under the purview of the District Securities Commission. ${ }^{60}$ This commission ${ }^{61}$ currently exercises control over the borrowings of irrigation districts and Califorma water districts (not county water districts), acts in an advisory capacity to cities and counties undertaking reclamation projects, ${ }^{62}$ and reviews financial operations of other districts at their request. Commission review involves a feasibility study prior to sale of bonds to insure that a proposed venture is financially sound, and review of the expenditure of bond funds to guarantee that the money is spent for the purposes intended. It is proposed that commission jurisdiction be determined by a formula which will include those projects which might have danger potential, such as those lacking normal political safeguards due to a single owner-developer situation and those in which borrowing reaches a dangerously high percentage of present or anticipated valuation, and exclude those conventional districts whose internal control is sufficient to forestall marginal or speculative ventures. Such legislation, if enacted, would apply to all developer-districts. ${ }^{63}$

\section{County Waterworks Districts}

County waterworks districts ${ }^{64}$ may be establislied to provide for the supplying of the inhabitants of the district with water for irrigation, domestic use, or fire protection, and for the development and conservation of water supphes for those purposes. It may form improvement districts and utilize the Improvement Act of 1911, and may borrow money, issue

67 Proceedings re Special District Indebtedness at 78-85.

58 Id. at 67.

59 Id. at 85 .

60 Id. at 4.

61 CAL. WATER Code $\$ \S 20000-107$.

62 CAL. Gov'T CoDE $\$ \S 25681.1,38901$.

63 Assembly Bill 364 introduced in the 1965 legislative session would provide that District Securities Commission approval be required for any special district bond issue which would result in an indebtedness of greater than forty percent of the combined total of the value of the improvements to be constructed and the reasonable value of the land. Reasonable value would be calculated at four times the assessed valuation. Commission jurisdiction would continue until indebtedness became less than twice the total assessed valuation and until the district had at least one registered voter per every two acres.

64 CaL. Water Code $\S \S 55000-991$. 
bonds, and levy taxes. The district can be formed by majority vote in an election held pursuant to a petition signed by not less than twenty-five percent of the freeholders resident and non-resident, including not less than fifteen percent resident freeholders. ${ }^{65}$ Investigations by the Investment Fraud Unit of the Attorney General's office during the interim between the 1963 and 1965 legislative sessions disclosed four instances of such developer-districts in which district bonds were in default. ${ }^{66}$

\section{Resort Improvement Districts}

The powers of a resort improvement district ${ }^{67}$ are extensive. It may acquire, construct, maintain and operate property, works and facilities to supply water, provide sewage and garbage collection, treatment and disposal services, furnish fire protection, furnish "comprehensive planning for the physical growth of the area within the district," supply public recreational services, furnish street lighting, abate mosquitoes, furnish police protection, construct and repair streets and drainage facilities, and construct and mamtain parking facilities and other transportation facilities. For these purposes the district may borrow money, issue bonds, utilize the Improvement Act of 1911 and the Municipal Improvement Act of 1913, and levy taxes.

Ten percent of the registered voters in the proposed district may petition for an election. Majority vote is required to form the district. The county board of supervisors may act as the district board of directors, or, if the supervisors deem it desirable, the board may consist of one supervisor and four other directors who may be either electors of the district, owners of property in the district, or officers or legal representatives of corporate owners of property in the district. Under the authority of this 1961 legislation a petition signed by two persons was adequate to set in motion machinery which resulted in a general obligation bond issue of $4,250,000$ dollars, and an assessment district issue of 95,000 dollars. ${ }^{68} \mathrm{Al}-$ though there is no indication that the project may fail, it remains arguable that with such a relatively non-existent electoral base, there is far too little guarantee that such a large amount of public money will be solely devoted to the public interest.

\section{Municipal Utility Districts}

Districts formed under the Municipal Utilities Districts Law ${ }^{60}$ could,

65 CAL. WATER CODE \$ 55103.

60 Proceedings re Special District Indebtedness at 87-90.

67 CAT. PUB. REs. CODE \$§ 13000-233.

68 Proceedings re Special District Indebtedness at 86 . Assembly bill 366 introduced in the 1965 legislative session would curtail formation of resort improvement districts.

69 CAr. PuB. UtII. Code \$§ 11501-14509. 
until 1963, create improvement zones-districts within the special district -only to finance sewage facilities. A 1963 amendment allows formation of zones for sewage disposal, public recreation, or any of the many purposes which the entire district is authorized to accomplish. These purposes include providing the district's inhabitants with liglit, water, power, heat, transportation, telephone service, and other means of communication. The debt limitation which applies to the inunicipal utility district proper was made imapplicable to the zones. ${ }^{70}$ The Committee found that these amendments were devised specifically for one development project and cliaracterized thein as "designed to encourage speculative land development" and recommended that they be repealed. ${ }^{71}$

\section{Protection Districts}

Ventura county recently experienced efforts by land developers to form districts under the Protection District Act of $1907 .{ }^{72}$ The purpose of a Protection District is to protect lands from overflow or damage from water. It may accomplish this by acquiring lands by purchase, gift or condemnation, and constructing the necessary facilities thereon. Money may be borrowed, bonds issued, and taxes levied. This type of district offers these attractive features to land developers: Proceedimgs to form the district are mitiated by landowners; both owners and residents vote; there is no statutory debt limitation; public improvement costs are met by a tax on the value of land only, and not on constructed promotional improvements such as "elaborate clubhouses."73 The Ventura County Executive persuaded the board of supervisors to declare a moratorium on the formation of further protection districts because of the following questionable practices mvolved in their use: district boundaries have been gerrymandered; citizen participation and control is extremely himited; bonds are used to finance improvements normally considered the developers' responsibility; district engmeers in some cases serve two masters, the district and the subdivider; the act permits servicing only interest on bond indebtedness for the first ten years, resulting in an anticipated added interest burden of sixty percent to be met not by the developer but

70 CAT. PUB. UTII. CODE § 12843. General obligation indebtedness of Municipal Utilities Districts is limited to twenty percent of the assessed valuation of all real and personal property located in the district, CAL. PUB. UtIr. CODE $\$ 12842$, as is general obligation indebtedness of Community Service Districts, CaL. Gov'T CODE $\$$ 61613. None of the other districts discussed have statutory debt limitations.

71 Proceedings re Special District Indebtedness at 5.

72 Cac. Gen. Laws ANN. act 6175 (Deering, 1964).

73 Proceedings re Special District Indebtedness at 20-22. Only land value is taxed. Consequently early private improvers (the man who builds the first house) will not bear a disproportionate share of the burden of retiring the cost.of the public improvements during the early years of the debt. 
by the future homeowner; debt ratios are excessive, amounting to four hundred and five percent of assessed valuation in one district; taxes are excessive, as high as twenty-eight dollars per hundred rather than the four dollars per hundred projected in a feasibility study done by the district's financial consultant; and finally, the sytem induces leap-frog subdivision development, creating uncoordinated, disjointed communities. ${ }^{\mathbf{7 4}}$

\section{Special Act Special Districts}

The Committee in 1962 examined two special districts ${ }^{75}$ which had been tailor-made by special acts ${ }^{70}$ in the 1960 first extraordinary legislative session: Estero Municipal Improvement District,77 (better known as Foster City) and the Einbarcadero Municipal Improvement District. ${ }^{78}$ The Acts are virtually identical in their provisions. Each district was given broad authority to provide public improvements, including street

74 Ibid.

75 There are 118 special districts in California which were created by special act of the legislature. CONTROLLER'S ANNUAI REPORT at 19-22. The Estero district and the Embarcadero district were created specifically for development purposes.

76 The California constitution, article IV, § 25, provides that "The Legislature shall not pass local or special laws in any of the following enumerated cases," listing 32 prohibited categories ineluding "Authorizing the laying out, opening, altering, maintaining, or vacating roads, highways, streets, alleys, town plats, parks, cemeteries, graveyards, or public grounds not owned by the State; for the assessment and collection of taxes; providing for conducting elections; granting to any corporation, association or individual any special or exclusive right, privilege, or immumity"; and a thirty-third category, "In all other cases where a general law can be made applicable." Article XI, § 6, provides that "Corporations for municipal purposes shall not be created by special laws." Special laws for a variety of purposes have, however, long been upheld in California. The court in Alameda County Flood Control and Water Conservation Dist. v. Stanley, 121 Cal. App. 2d 308, 263 P.2d 632 (1953), reviewed the long line of cases upholding special legislation. It quoted with approval the language of Argyle Dredging Co. v. Chambers, 40 Cal. App. 332, 342, 181 Pac. 84, 88 (1919), that "the Legislature must, in the first instance, determine whether or not a general law can be made applicable in the particular case. The court will not interfere with its judgment on the subject, unless it clearly and beyond a reasonable doubt appears that it adjudged contrary to the fact." The court also approved the even stronger language of Reclamation Dist. No. $70 \mathrm{v}$. Shernian, $11 \mathrm{Cal}$. App. 399, 407-08, 105 Pac. 277, 281 (1909), that "It would require a clear showing upon the face of the law itself that a special act was not required before a court would interfere with the determination of a coordinate branch of the government upon this subject. ..."

Special districts have been construed to be either state agencies or quasi-mumicipal corporations, and thus not "corporations for municipal purposes" and therefore not prohibited by article XI, section 6. Brooks, The Metropolis, Home Rule, and the Special District, 11 Hastings L.J. 110, 119-25 (1959).

77 Cal. Stats. 1960, ch. 82 (1st Ex. Sess.), as amended. Foster City comprises an area of approximately 2800 acres, located on the San Francisco Bay in San Mateo County.

${ }^{78}$ Cal. Stats. 1960, ch. 81 (1st Ex. Sess.), as amended. This project is located along the Pacific Ocean north of Santa Barbara, Calif., comprising an area of approximately 1320 acres. 
and highway highting facilities; sewage, garbage, and refuse disposal services; park and recreational services; reclamation of submerged lands; and fire and police protection. In providing these services the districts were allowed to issue revenue and general obligation bonds and to form special assessment districts. ${ }^{79}$ Experience with the two districts was, however, anything but identical. Two Embarcadero directors were convicted of grand theft, conspiracy and Corporations Code violations in connection with their district dealings. The Estero District, on the other hand, appears to be a successful operation. This may be attributed to the integrity of the developer and his willingness voluntarily to secure county approval of his development and to provide other public safeguards, rather than to any inherent safeguards in the Act creating the district. ${ }^{80}$

The Committee made three legislative suggestions with regard to these districts. The first proposal was that realistic fidehty bonds be made mandatory for directors. The 1963 legislature responded by providing that should the district use a depositary other than the county treasurer, a finance officer should be appointed and should be bonded for at least 250,000 dollars. ${ }^{81}$ The second recommendation was that one of the directors be an outsider, a person who was neither an owner nor an agent of an owner and who had no direct interest in the financial success of the district. Embarcadero was in receivership, so the recommendation was superfluous as applied to it. The Estero Act, as amended, in effect put the legislative seal of approval on a practice which the district had already adopted. The third recommendation, for county review of district financial operations, was satisfied by the enactınent of a uniform system of accounting for special districts. ${ }^{82}$

\section{III}

\section{CONTROLLING SPECIAI DISTRICT INDEBTEDNESS}

\section{A. Objections to the Practice}

The use of assessment areas and special districts as aids in financing land development has not met everywhere with wholehearted approbation. Many objections have been voiced: (1) If the developer's credit rating does not enable him to finance through the conventional money market, perhaps the public is not wise in entrusting funds to such a marginal operator; ${ }^{83}$ (2) existence of easy financing for public improvements imdu-

796 Conartitee, Finat Report 33.

806 CoMrartitee, Finat Report 8.

81 Both the Estero Act and the Embarcadero Act were amended to so provide. Cal. Stats. 1963, ch. 995.

82 See note 53 supra and accompanying text.

83 See, e.g., testimony of Edward Eichler, "The only time I know of now where a bank or a savings and loan will not provide financing which, though very expensive, is still 
ces the developer to seek cheap land far from existing improvements rather than land in the normal path of urban growth whose higher price reflects the availability of nearby governmental services-the result is urban sprawl and its attendant waste of resources; ${ }^{84}(3)$ allowing substantially private developmental operations to clothe themselves in a governmental character in order to enter the municipal bond market is governmental action for private rather than public purposes and thus constitutes the lending of public credit in violation of the California constitution. ${ }^{85}$

cheaper than the net costs of the assessment district-the only time they will not do this is when they don't trust the record of the operator or when they don't trust the market. I would say that if a situation occurs about which a bank or savings and loan makes either of these judgments, I wonder whether the government ought to be involved in providing support." Proceedings re Tax Exempt Bonds, at 42. For a contrary view, see discussion note 11 supra and accompanying text.

84 Committee, Staff Report, in Proceedings re Special District Indebtedness at 23; Proceedings re Tax Exempt Bonds at 44-45.

85 This seemingly is the argument advanced by the Cahifornia State Treasurers Office in equating bonds for land development and so-called industrial bonds. Proceedings re Tax Exempt Bonds at 5. Programs designed to encourage industry through a variety of means embracing public borrowing have been authorized in thirty states. The constitutionality of these various programs has been attacked on the grounds that they violate state constitutional provisions probibiting the lending of pubhic credit in aid of persons, corporations or associations. See Pinsky, supra note 11. Disillusionment through experience with state and municipal loans and gifts to railroads in the mineteenth century led many states to enact constitutional limitations on the power of the state to lend its credit or to make gifts to or invest in private enterprise. See e.g., CaI. Const. art. IV, \& 31. The constitutional movement produced a complementary judicial reaction, the enunciation of the public purpose doctrine: that taxes could be levied only for public purposes and that any purported tax statute which crossed the public-private barrier would violate the due process clause of the state constitution as a taking of property for private use. Two aspects of the doctrine became apparent; first, that the public should not assume the risks inherent in the nature of some enterprises; and second, that the public should not assume the risks flowing from uncontrolled private decision making. The public purpose doctrine was subsequently imcorporated by the United States Supreme Court into the fourteenth amendment. Jones v. City of Portland, 245 U.S. 217 (1917).

Such industrial development programs have been judicially invalidated in Arkansas, Florida, Nebraska, Idaho and Ohio, as the lending or giving of public credit in violation of state constitutional provisions. Elsewhere they have been deemed valid as having a public rather than a private purpose. The United States Supreme Court dismissed an appeal from the first decision holding such a program constitutional, Albritton v. City of Winona, 181 Miss. 75, 178 So. 799, appeal dismissed, 303 U.S. 627, (1938), on the grounds that no substantial federal question was involved, citing Green v. Frazier, 253 U.S. 233 (1920), which stands for the proposition that great deference will be given the finding of a state legislature and state courts that a particular governmental endeavor has a public purpose.

California decisions interpreting the constitutional prolibition of public gifts are very thoroughly discussed in Veterans' Welfare Board v. Jordan, 189 Cal. 124, 208 Pac. 284 (1922), which held constitutional a bond issue to provide funds to acquire, subdivide and improve land, and to sell the land so improved to veterans at cost, while striking down the severable portions of the same act insofar as they were directed towards mere purchase of land and sale to veterans on credit, and insofar as directed towards loans to 
There is also concern with the possible effects on the totality of state and local government borrowing. It is feared that governmental borrowing for land development, characterized as a "marginally public" undertaking, will, by adding to total public debt, contribute to a decline in the governmental entity's competitive position in the bond market and to the corresponding rise in costs of borrowing. The ability then to meet more clearly-legitimate public needs, such as scliools and parks for already existing communities, will be prejudiced. There also is the fear that failure or rumored failure in a developmental bond issue will prejudice other governmental borrowing. ${ }^{86}$

Another objection is made on the ground that governmental borrowing for such marginally public objectives is much akin to the practice of an increasing number of states of authorizing issuance of public "industrial" bonds to finance plant construction to attract industry. The tax exemption provision there, which remains under intensive fire, may, it is feared, provide the entering wedge in the never dormant campaign to eliminate the tax exemption on state and local government obligations altogether. ${ }^{87}$

veterans to enable them to buy personal property to enable them to carry on farming operations. The distinction, the court said, was that the former aspect had a separate and distinct incident, a land settlement plan, by which an agency of the state would secure land, conduct water to it, and provide for water distribution. This, the court found, was closely analogous to irrigation and reclamation district laws, long held constitutional, and therefore valid as authorizing the spending of public money for a public purpose. Since the money raised was to be applied to this public purpose, the incidental benefit to the veteran-purchaser would not render the act invalid. $I d$. at 145-46, $208 \mathrm{Pac}$. at 293. The court relied heavily on Green v. Frazier, supra, calling that decision of great, if not controlling, importance. Id. at 141, 208 Pac. at 291.

In light of Veterans Welfare Board and the oft-reiterated policy of allowing great deference to the legislative determination that an undertaking has a public purpose, County of San Mateo v. Cohurn, 130 Cal. 631, 634, 63 Pac. 78, 79 (1900), Monterey County Flood Control \& Water Conservation Dist. v. Hughes, 201 Cal. App. 2d 197, 209, 20 Cal. Rptr. 252, 259 (1962) (recital by state legislature); City of Roseville v. Tulley, 55 Cal. App. 2d 601, 606, 131 P.2d 395, 400 (1942) (recital by local legislative body), it appears safe to conclude that the legislatively sanctioned use of public borrowing procedures by land developers would easily survive challenges based on the constitutional prohibition of public gifts and public loans of credit.

86 See, e.g., Testimony by Claude Richards, chairman of the Municipal Securities Committee, Investment Bankers Association, Proceedings re Independent Special Districts at 69-73; Testimony by Richard Munden, Deputy Cahfornia State Treasurer, id. at 79-82, and in Proceedings re Tax Exempt Bonds at 5-10; Testimony by Alan Bartleth, Assistant Vice-President, Bank of America, id. at 10-25.

87 See, e.g., Proceedings re Tax Exempt Bonds at 6; Pinsky, supra note 11, at 275. Bonds issued by or on behalf of a municipality for the purpose of financing the acquisition or construction of municipally-owned industrial plants for lease to private industry constitute obligations of a political subdivison of a state within the meaning of the Internal Revenue Code and are thus tax exempt. Rev. Rul. 54-106, 1954-1 CuM. BuLI. 28. If the bonds are issued not by a public corporate body but by a corporation formed under the state's general non-profit corporation law, then the following requirements must be met: the corporation's activities must be essentially public in nature; it must 
There is considerable validity to eacl of these objections. Even when considered together, however, their existence does not demand total abandonment of the use of tax exempt bonds for financing public improvements in subdivisions. Instead it requires that the legislature tread the fine line which will at one time meet these objections and at the same time preserve to the state the imtended economic benefit.

\section{B. The Extent of Public Control}

Those who object to the use of assessment bonds and special district bonds in land development probably will agree that if the practice is to continue, adequate control measures must be maintained to msure that the fears of the objectors are not realized, that borrowing for development does not so burden the property as to hamper future capacity to finance essential governmental services, and that overly speculative ventures whose failures might adversely affect local credit standing are not undertaken.

Some minimal safeguards have always been present. One primary form of control is provided by the bond market itself. Bond underwriters must satisfy themsleves of the feasibility of a project in order to protect profit and reputation. Performance and fidelity guarantors have similar interest to protect and can be expected to exert a similar controlling influence. Bid, bond, notice and hearing requirements have been and remain salient features of the statutory scheme. ${ }^{88}$

not be operated for profit; the corporation's profits must not mure to any private person; the state or political subdivision must have a beneficial interest during the indebtedness and must secure full legal title to the property which the non-profit corporation financed; and the non-profit corporation and its obligations must have been approved by the state or a political subdivision. Rev. Rul. 63-20, 1963-1 CuM. BviL. 24.

The United States Advisory Conmission in its report entitled Industrial Development Bond Financing (June 1963) finds those bonds an improper use of tax exemption, and accordingly, recomniends limitations and safeguards, one recommendation being that only units of general government, and not special purpose districts, be allowed to issue such bonds. The commission found particularly improper the practice followed by some industrial beneficiaries, who, supposedly induced through the use of plant construction financing not otherwise available, proceeded to buy the bonds issued to construct the plant they occupied. Id. at 21. For an analogous practice in the context of a California reclamation district, see Commissioner v. Birch Ranch \& Oil Co., 192 F.2d 924 (9th Cir.), affirming 13 T.C. 930 (1951), where land owners whose property constituted nearly the entire district issued bonds to finance improvements, and then, through a closely held family corporation, purchased the bonds, deducting interest paid as an expense, and receiving tax exempt interest on the bonds held. The court refused to disregard the public corporate intermediary and reversed the Commissioner's disallowance of the interest deduction.

88 Hearing and notice provisions and bid and bond requirements are a part of every procedure outlined. The problems arise when there are none to hear and none to bid except those whose primary financial interest is unchecked. See, e.g., text accompanying note 28 supra. 
Additional safeguards have been established by recent legislation. Criminal sanctions have been brought to bear more closely upon the area ${ }^{89}$ Provision has been made for review of project feasibility and desirability at the formation stage by the entity authorizing the improvement, and, in the case of special districts, by the local agency formation commission as well. ${ }^{90}$

Legislation directed towards the remaining problem areas has been proposed in the current session. The District Securities Approval Law ${ }^{91}$ would provide for additional expert assurance of project feasibility and consequently of the value of the purchasers investment and the bondholder's security. The District Reorganization $\mathrm{Act}^{22}$ would provide for a means of co-ordinating more efficiently the many, varied, and often overlapping governmental functions performed by the numerous local public districts.

\section{CONCLUSION}

The increasing use of special assessment procedures and independent special districts as aids in financing land development has occasioned a reexamination of these procedures, since the basic acts were for the most part designed to meet different needs. The attractiveness of the procedures rests in part upon the ready market for low interest obligations which the tax exempt character of the bonds guarantees. The tax exemption seems in no danger at present, althougl strong pressures continue to be exerted to remove it on the somewhat analagous industrial development bonds. Investigations and hearings carried on during the interim between the 1961 and 1963 legislative sessions led to recommendations embodied in the Final Report of the Assembly Interim Committee on Municipal and County Government. The 1963 legislature made practically a blanket enactment of those recommendations. It may be inferred that the legislature has for the present given only a qualified endorsement to the practice. Continued legislative scrutiny is indicated, and should be anticipated. ${ }^{93}$

\section{Gerald E. Mullen}

80 The 1963 Legislature amended the Cahfornia Penal Code to provide that the proceeds of funds derived from the sale of bonds or other evidence of indebtedness authorized by the legislative body of any district, as well as that of any city, county, or public agency, would be considered "public inoneys," with misappropriation punishable in the former as well as the latter. CAL. PEN. CODE $\$ 424$.

89 See note 55 supra and accompanying text.

81 See notes 60-63 supra and accompanying text.

92 See note 55 supra.

93 For additional relevant material which becaune available too late to be integrated into this Comment, see the 1965 Report of the Committee on Mumicipal and County Government, 6 Comamtree, Final Report No. 22, (1965), and UNITEd States Advisory Comantssion on Intergovernanental Retations, Report on Spectal Purpose Districts (1965). 